\title{
Temperature effect on tert-butyl alcohol (TBA) biodegradation kinetics in hyporheic zone soils Mark H Greenwood ${ }^{1,2}$, Ronald C Sims*2,3, Joan E McLean ${ }^{1,2,3}$ and William J Doucette $e^{1,2}$
}

\author{
Address: ${ }^{1}$ Division of Environmental Engineering, Utah State University, Logan, Utah 84321, USA, ${ }^{2}$ Utah Water Research Laboratory, Utah State \\ University, Logan, Utah 84321, USA and ${ }^{3}$ Department of Biological and Irrigation Engineering, Logan, Utah 84321, USA \\ Email: Mark H Greenwood - markgreen@cc.usu.edu; Ronald C Sims* - rcsims@cc.usu.edu; Joan E McLean - jmcl@cc.usu.edu; \\ William J Doucette - doucette@cc.usu.edu \\ * Corresponding author
}

Published: 19 September 2007

BioMedical Engineering OnLine 2007, 6:34 doi:10.1 I86/1475-925X-6-34
Received: 2 June 2007

Accepted: 19 September 2007

This article is available from: http://www.biomedical-engineering-online.com/content/6/1/34

(C) 2007 Greenwood et al; licensee BioMed Central Ltd.

This is an Open Access article distributed under the terms of the Creative Commons Attribution License (http://creativecommons.org/licenses/by/2.0), which permits unrestricted use, distribution, and reproduction in any medium, provided the original work is properly cited.

\begin{abstract}
Background: Remediation of tert-butyl alcohol (TBA) in subsurface waters should be taken into consideration at reformulated gasoline contaminated sites since it is a biodegradation intermediate of methyl tert-butyl ether (MTBE), ethyl tert-butyl ether (ETBE), and tert-butyl formate (TBF). The effect of temperature on TBA biodegradation has not been not been published in the literature.

Methods: Biodegradation of [U $\left.{ }^{14} \mathrm{C}\right]$ TBA was determined using hyporheic zone soil microcosms.

Results: First order mineralization rate constants of TBA at $5^{\circ} \mathrm{C}, 15^{\circ} \mathrm{C}$ and $25^{\circ} \mathrm{C}$ were $7.84 \pm 0.14$ $\times 10^{-3}, 9.07 \pm 0.09 \times 10^{-3}$, and $15.3 \pm 0.3 \times 10^{-3}$ days-I, respectively (or $2.86 \pm 0.05,3.31 \pm 0.03$, $5.60 \pm 0.14$ years $^{-1}$, respectively). Temperature had a statistically significant effect on the mineralization rates and was modelled using the Arrhenius equation with frequency factor $(A)$ and activation energy (Ea) of I54 day-1 and 23,006 mol/J, respectively.

Conclusion: Results of this study are the first to determine mineralization rates of TBA for different temperatures. The kinetic rates determined in this study can be used in groundwater fate and transport modelling of TBA at the Ronan, MT site and provide an estimate for TBA removal at other similar shallow aquifer sites and hyporheic zones as a function of seasonal change in temperature.
\end{abstract}

\section{Background}

The presence of methyl tert-butyl ether (MTBE) and the biodegradation intermediate tert-butyl alcohol (TBA) in shallow aquifer systems affected by seasonal low temperature groundwater $\left(\sim 5^{\circ} \mathrm{C}\right)$ have been widely reported [e.g. $[1,2]]$. In the past, the use of monitored natural attenuation (MNA) as a remediation alternative at MTBE and TBA contaminated sites in low temperature climates has had questionable utility because of the low rate of biodegradation anticipated to occur at low temperatures.

Mesophilic microbial communities show optimum growth and biodegradation of substrates from $20^{\circ} \mathrm{C}$ to $40^{\circ} \mathrm{C}$ and become ineffective at $5^{\circ} \mathrm{C}[3,4]$. Subsurface contaminant remediation with winter temperatures below $5{ }^{\circ} \mathrm{C}$ would become temporarily depressed through part of the year since these systems are predominated by 
mesophilic microbial communities. However, MNA may remain an effective remediation year round if the microbial community is psychrotolerant, which is characteristic of having optimum temperature ranges from $15^{\circ} \mathrm{C}$ to $30^{\circ} \mathrm{C}$ and becoming ineffective at $0^{\circ} \mathrm{C}[4]$.

Multiple studies have reported the bioremediation of groundwater contaminants including $\mathrm{MTBE}$, aromatic hydrocarbons, and alkanes at or below $5{ }^{\circ} \mathrm{C}$ with significant removal [5-8], which demonstrates the applicability of MNA at contaminated groundwater sites in lower temperature regions. Significant biodegradation of MTBE from $4{ }^{\circ} \mathrm{C}$ up to $34^{\circ} \mathrm{C}$ was observed by Bradley and Landmeyer [5] in soils from a MTBE contaminated site in Ronan, Montana. The effect of temperature on TBA biodegradation, the primary degradation intermediate of MTBE, has not been published in the literature. The presence of TBA in shallow aquifers at low temperatures may be the rate limiting step for remediating a MTBE contaminated site using MNA. TBA can be stoichiometrically formed not only from MTBE but also from ethyl tert-butyl ether (ETBE) and tert-butyl formate (TBF), which are now used as fuel additives in place of MTBE [9]. Also, TBA has been found to be present in gasoline up to $11 \%$ of the volume of MTBE as an impurity [10]. Therefore, the presence of TBA, a potential human carcinogen [11] and one of the most mobile gasoline LUFT contaminants [12], in the environment could soon be more pertinent than that of MTBE.

The purpose of this study was to observe the effect of temperature on TBA biodegradation kinetics in soils within the hyporheic zone of the shallow MTBE and TBA contaminated aquifer in Ronan, MT. The hyporheic zone is defined as the region of interaction between groundwater (low dissolved oxygen (DO) and high in nutrients) and surface water (high DO and low in nutrients). Hyporheic zones have been observed to exhibited increase in the rate of biodegradation of dissolved organic carbon (DOC) that was not otherwise degraded in surface and subsurface waters [13-15]. The authors attributed the increased biodegradation rate to the interaction of the groundwater and surface water where exchanges of nutrients, oxygen, and organic matter stimulated hyporheic zone microbe activity. This study examined the effect of temperature range from 5 to $25^{\circ} \mathrm{C}$ on the degradation rate of TBA in aerobic microcosms containing soil collected from the Ronan hyporheic zone.

\section{Methods \\ Chemicals}

TBA (>99.9\% HPLC grade) was purchased from Sigma Aldrich Chemical Co., Bellefont PA and was used as received. Uniformly labelled [U $\left.{ }^{14} \mathrm{C}\right]$ TBA (> 98\% purity; $4.0 \mathrm{mCui} \mathrm{mmol}^{-1}$ ) was obtained from Nuclear Research Products, Du Pont, Boston, MA.

\section{Study site}

The MTBE contaminated site in Ronan, Montana (located 170 kilometers north of Missoula, Montana) was created by a leaking underground fuel tank (LUFT) that released approximately 22,000 litters of gasoline in 1994 [16]. The spill created an MTBE free product plume that moved west under Highway 93 and a dissolved plume that travelled

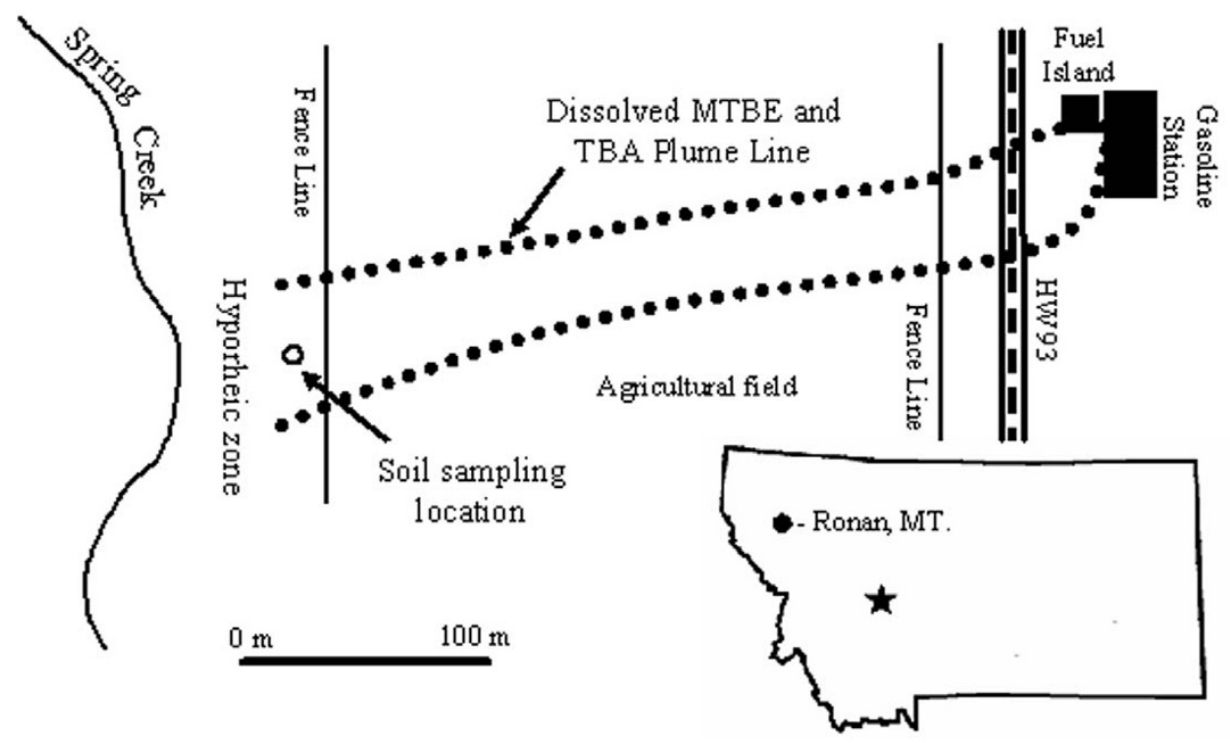

Figure I

Ronan, MT MTBE plume site and hyporheic zone. 
under an agricultural field towards Spring Creek located approximately 460 meters west of the spill site (Figure 1). The contaminated aquifer is up to 5 meters below ground surface (bgs) near the gasoline station and at surface discharge (zero $\mathrm{m}$ bgs) in the Spring Creek hyporheic zone located between the creek and the agricultural field fence line [16]. Groundwater concentrations of MTBE and TBA in the hyporheic zone were $1000 \mu \mathrm{g} / \mathrm{L}$ and $500 \mu \mathrm{g} / \mathrm{L}$, respectively, in 2002. The maximum dissolved concentrations of MTBE and TBA reported at the site were $7000 \mu \mathrm{g} /$ $\mathrm{L}$ and $1000 \mu \mathrm{g} / \mathrm{L}$, respectively.

All contaminated groundwater at the site enters Spring Creek via the hyporheic zone, which creates a seasonal wetland between Spring Creek and fence line. Groundwater discharging into Spring Creek, after passing through the hyporheic zone, contains only $300 \mu \mathrm{g} / \mathrm{L} \mathrm{MTBE}$ and non-detectable $(<5 \mu \mathrm{g} / \mathrm{L})$ concentration of TBA. However, the growth of the TBA plume may result in increased flux of TBA into Spring Creek [16].

\section{Soil/aquifer materials}

A soil sample was collected $30 \mathrm{~cm}$ bgs in the hyporheic zone of the Ronan, MT site along the centreline of the MTBE plume (Figure 1). The soil sample was taken approximately $20 \mathrm{~cm}$ bgs and stored in sterilized glass containers at $4{ }^{\circ} \mathrm{C}$ in the dark. Soil characteristics are $\mathrm{pH}$ of 7.7 , percent organic carbon of $6.80 \%$, and percent sand, silt, and clay of $27 \%, 51 \%$, and $22 \%$, respectively with nutrient and chemical concentrations of $46 \mathrm{mg} / \mathrm{kg}$ phosphorous, $144 \mathrm{mg} / \mathrm{kg}$ potassium, $6.11 \mathrm{mg} / \mathrm{kg}$ nitrate, $3.18 \mathrm{mg} / \mathrm{kg}$ zinc, $200 \mathrm{mg} / \mathrm{kg}$ total iron, $3.21 \mathrm{mg} / \mathrm{kg}$ copper, $44.6 \mathrm{mg} / \mathrm{kg}$ manganese, and $25.4 \mathrm{mg} / \mathrm{kg}$ sulfate.

\section{Microcosm experiment}

Each microcosm consisted of a 40-ml volatile organic airtight (VOA) vial with one $7-\mathrm{ml}$ vial and a $1.5-\mathrm{ml}$ micro- fuge tube (Figure 2). The $7-\mathrm{ml}$ vial contained 1.5 grams of soil with $5 \mathrm{ml}$ of $2000 \mu \mathrm{g} / \mathrm{L} \mathrm{TBA}$ solution and $0.1 \mu \mathrm{Ci}$ [U $\left.{ }^{14} \mathrm{C}\right] \mathrm{TBA}$. The $1.5 \mathrm{ml}$ centrifuge tube contained $1 \mathrm{ml}$ of 1.5 $M$ potassium hydroxide $(\mathrm{KOH})$ solution used to trap carbon dioxide $\left(\mathrm{CO}_{2}\right)$ (Figure 2$)$.

After collection of $\mathrm{CO}_{2}$ in $\mathrm{KOH}, 0.5 \mathrm{ml}$ of $1.5 \mathrm{M}$ barium chloride $(\mathrm{BaCl})$ was added to each trap to precipitate ${ }^{14} \mathrm{CO}_{2}$ to form insoluble barium carbonate. After centrifugation at 13 gs for 10 minutes, supernatant containing [U $\left.{ }^{14} \mathrm{C}\right]$ TBA was pored off leaving the barium carbonate pelt at the bottom. Each pelt was re-volatilized with $0.25 \mathrm{ml}$ of $20 \%(\mathrm{v} / \mathrm{v})$ hydrochloric acid in a 40-ml VOA vial containing a $7-\mathrm{ml}$ glass vial with $1 \mathrm{ml}$ of $0.5 \mathrm{M} \mathrm{KOH}$ solution to capture ${ }^{14} \mathrm{CO}_{2}$ (Figure 2). After equilibration on a shaker table for 24 hrs, 6 mls of scintillation cocktail was added to the $7 \mathrm{ml}$ vial and analyzed by liquid scintillation counting. It is important to note that, using this indirect way, only the carbon of mineralized TBA $\left({ }^{14} \mathrm{CO}_{2}\right)$ was measured and not [U $\left.{ }^{14} \mathrm{C}\right]$ TBA.

Microcosms were incubated at 5,15 , and $25^{\circ} \mathrm{C}$ in the dark and $\mathrm{CO}_{2}$ traps were replaced every $4-8$ days for 220 days (with exception of sampling times 200 and 220, where traps where replaced after 20 days). The continual replacement of the $\mathrm{CO}_{2}$ traps every 4-8 days provided exposure of the system to atmospheric oxygen to maintain oxic conditions. Poisoned controls, non-poisoned controls, soil slurry blanks (soil slurry with no TBA), and water spikes (water with TBA only) were used to confirm biological degradation of TBA and to prevent false positives. The soil was poisoned with mercuric chloride $\left(\mathrm{HgCl}_{2}\right)$ at $1000 \mathrm{mg} /$ $\mathrm{kg}$ soil and autoclaved twice for one hour each. Final concentrations of $\left[\mathrm{U}^{14} \mathrm{C}\right] \mathrm{TBA}$ in the microcosms where measured by scintillation counting of $1 \mathrm{ml}$ of solution in $6 \mathrm{ml}$ of scintillation cocktail.

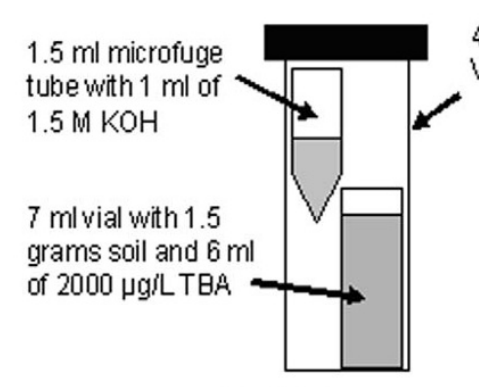

TBA Microcosm
$40 \mathrm{ml}$ VOA vial

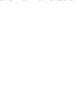

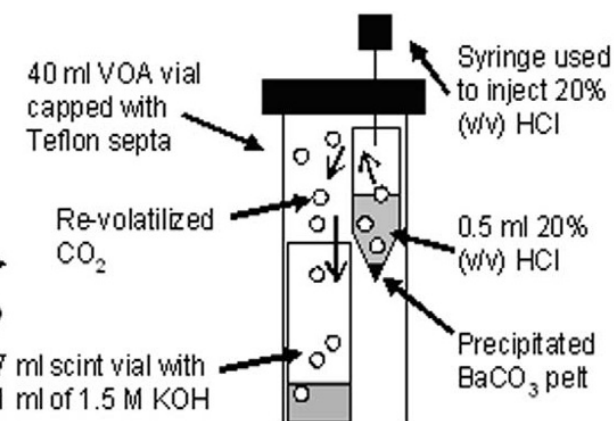

$\mathrm{CO}_{2}$ re-volatilization

Figure 2

Experimental microcosm and $\mathrm{CO}_{2}$ re-volatilization setups. 


\section{Results}

Total mineralization of TBA in non-poisoned soil microcosms at $5^{\circ} \mathrm{C}, 15^{\circ} \mathrm{C}$, and $25^{\circ} \mathrm{C}$ after 220 days was $54.0 \%$, $64.4 \%$, and $69.8 \%$, respectively (initial concentration of $2000 \mu \mathrm{g} / \mathrm{L}$ ). All control samples (including poisoned microcosms) had zero readings of ${ }^{14} \mathrm{CO}_{2}$. The non-poisoned microcosm soil slurry was measured on day 220 with no detectable scintillation counts. Therefore, $46.0 \%$, $35.6 \%$ and $30.2 \%$ of the [U $14 \mathrm{C}$ ] TBA at $5^{\circ} \mathrm{C}, 15^{\circ} \mathrm{C}$, and $25^{\circ} \mathrm{C}$, respectively, were not recovered as ${ }^{14} \mathrm{CO}_{2}$.

Since TBA is miscible in water with a Henry's constant of $4.9 \times 10^{-4} \mathrm{~atm}-\mathrm{m} 3 / \mathrm{mol}$ (at $25^{\circ} \mathrm{C}$ ), it is assumed that the compound would remain in solution and only a small amount would partition into the headspace. Assuming that all of the headspace in the microcosm (volume of 30 $\mathrm{ml}$ ) was replaced with ambient air (void of TBA) every time the $\mathrm{CO}_{2}$ traps were replaced and the headspace (not including the $\mathrm{CO}_{2}$ trap solution) had reached equilibrium with the slurry, less than $0.01 \%$ of the TBA would have been removed from the microcosms at an incubation temperature of $25^{\circ} \mathrm{C}$.

Therefore, it was assumed that TBA in the slurry reached equilibrium with the $\mathrm{CO}_{2}$ trap along with the headspace in the microcosm. This was observed in an experiment where the supernatant from poisoned microcosm (no biological activity) $\mathrm{CO}_{2}$ traps were counted after 4,11 , and 18 days of incubation under identical conditions in the $5^{\circ} \mathrm{C}, 15^{\circ} \mathrm{C}$, and $25^{\circ} \mathrm{C}$ microcosms studies. With an initial concentration of $2000 \mu \mathrm{g} / \mathrm{L}$ in the soil slurry, the cumulative percent removal of TBA via partitioning (i.e. percent TBA detected in the $\mathrm{CO}_{2}$ trap) in the $5^{\circ} \mathrm{C}, 15^{\circ} \mathrm{C}$, and $25^{\circ} \mathrm{C}$ poisoned microcosms was $18.5 \%, 23.5 \%$, and $29.6 \%$, respectively. Therefore, the determination of the first order mineralization rate was corrected for the removal of TBA via partitioning into the $\mathrm{CO}_{2}$ trap.

\section{Theory}

The change in concentration of TBA over time in the microcosm was caused by biodegradation and partitioning of TBA into the $\mathrm{CO}_{2}$ trap. The rate of change equation for this system is

$$
\frac{d C}{d t}=k_{m} \cdot C+r_{p} \cdot C
$$

where $\mathrm{C}$ is the concentration of TBA $(\mu \mathrm{g} / \mathrm{L})$ in the water soil slurry, $\mathrm{dC} / \mathrm{dt}$ is the rate of change of the concentration of TBA over time, and $k_{m}\left(\right.$ day $\left.^{-1}\right)$ and $r_{p}\left(\right.$ day $\left.^{-1}\right)$ are the first order rate constants of mineralization and partitioning of TBA, respectively. This model assumes that TBA mineralization follows first order kinetics and that TBA loss via partitioning can be modelled by a first order constant (i.e. the actual rate of removal of TBA via partitioning will change over time and can only be averaged over the incubation time). Since the partitioning rate constant is a pseudo first order rate constant, it is represented by $r_{p}$ and not $\mathrm{k}_{\mathrm{p}}$ (first order rate of partitioning). Integration and manipulation of equation 1 provides the change in total mass of TBA with respect to time

$$
M s=M_{s o} \cdot e^{-\left(k_{m}+r_{p}\right) \cdot t}
$$

where $M_{S}(\mu \mathrm{g})$ is the mass of TBA $\left(M_{S}=C \cdot V_{S}\right.$, where $V_{S}$ is the volume of the slurry in liters) in the slurry at time $\mathrm{t}$, $\mathrm{M}_{\mathrm{SO}}$ is the initial mass of TBA at $\mathrm{t}=0$, and $\mathrm{t}$ is time in days. Additionally, the rate of change of TBA that included mineralization and removal via partitioning can also be determined with equations 3 and 4

$$
\begin{aligned}
& \frac{d M_{m}}{d t}=k_{m} \cdot M_{s} \\
& \frac{d M p}{d t}=r_{p} \cdot M s
\end{aligned}
$$

where $M_{m}(\mu g)$ and $M_{p}(\mu g)$ are the mass of TBA mineralized and partitioned, respectively. Substitution of equation 2 into equations 3 and 4 and integration of each equation provides

$$
\begin{aligned}
& M_{m}=\frac{k_{m} M_{s o}}{k_{m}+r_{p}}\left(1-e^{-\left(k_{m}+r_{p}\right) \cdot t}\right) \\
& M_{p}=\frac{r_{p} M_{s o}}{k_{m}+r_{p}}\left(1-e^{-\left(k_{m}+r_{p}\right) \cdot t}\right)
\end{aligned}
$$

Since the mass of TBA partitioned was not measured in this study, the expected mass $\left[\mathrm{M}_{\mathrm{pm}}(\mu \mathrm{g})\right]$, was determined through a mass balance equation based on the measured mineralization of TBA $\left[\mathrm{M}_{\mathrm{mm}}(\mu \mathrm{g})\right]$ and the predicted mass remaining in the slurry $\left(\mathrm{M}_{\mathrm{S}}\right)$.

$$
M_{p m}=M_{s o}-\left(M_{s}+M_{m m}\right)
$$

$\mathrm{k}_{\mathrm{m}}$ and $\mathrm{r}_{\mathrm{p}}$ values were determined through minimizing the sum of the differences squared of the measured or expected values $\left(\mathrm{M}_{\mathrm{mm}}\right.$ and $\left.\mathrm{M}_{\mathrm{pm}}\right)$ and the predicted values $\left(\mathrm{M}_{\mathrm{m}}\right.$ and $\left.\mathrm{M}_{\mathrm{p}}\right)$. This approach assumes that all samples have the same variance.

$$
\min =\sum\left(\frac{\left(M_{m m}-M_{m}\right)}{M_{m}}\right)^{2}+\sum\left(\frac{\left(M_{p m}-M_{p}\right)}{M_{p}}\right)^{2}
$$


Rate constants at the three specified temperatures were then applied to the Arrhenius equation for development of the Arrhenius constants: frequency factor $\left(\mathrm{A}, \mathrm{day}^{-1}\right)$ and activation energy $\left(E_{a^{\prime}}, \mathrm{mol} / \mathrm{J}\right)$ as seen in the equation

$$
k_{T}=A \cdot \exp \left(\frac{E_{a}}{R \cdot T}\right)
$$

where $\mathrm{k}_{\mathrm{T}}$ is a first order rate $\left(\right.$ day $\left.^{-1}\right)$ at temperature $\mathrm{T}(\mathrm{K})$ and $\mathrm{R}$ is the ideal gas constant $(8.314 \mathrm{~J} / \mathrm{mol} \cdot \mathrm{K})$. Equation 9 can be linearized by taking the natural log of both sides, that yields:

$$
\ln \left(k_{T}\right)=\frac{-E_{a}}{R \cdot T}+\ln (A)
$$

Plotting the $\ln \left(\mathrm{k}_{\mathrm{T}}\right)$ vs $1 / \mathrm{RT}$ will provide a line with intercept of $\ln (\mathrm{A})$ and slope of $\mathrm{E}_{\mathrm{a}}$.

\section{Mineralization rates}

Mineralization of TBA at $5^{\circ} \mathrm{C}$ and $15^{\circ} \mathrm{C}$ each had lag phases of 23 days before entering a log phase of mineralization, and microcosms incubated at $25^{\circ} \mathrm{C}$ had a lag phase of 14 days (Figure 3). Regression, using equation 5 and 6 , and data plots with 95\% upper and lower confidence intervals for increase in mineralization with time are presented in Figure 3. Reports presented in Table 1 include first order kinetic rate constants for mineralization $\left(\mathrm{k}_{\mathrm{m}}\right)$ and removal rate constants via partitioning $\left(\mathrm{r}_{\mathrm{p}}\right)$ of TBA determined from equations 5 and 6 , total percent mineralization, initial concentration at the end of the lag phase $\left(\mathrm{M}_{\mathrm{SO}}\right)$, and the minimum of the sum of the differences squared for each incubation temperature. Mineralization rates of TBA at the three temperatures where shown to be statistically different by using the method of least squares.
Comparison of TBA mineralization rates observed in this study to other published values can be seen in Table 2 . Only two studies have reported degradation rates for TBA and both were under different redox conditions $[19,20]$. The study by Schirmer et al. [19] used microcosms with soil from the aquifer at the Canadian Force Base (CFB) Borden (Ontario, Canada). The Borden aquifer was used in a natural gradient experiment with dissolved MTBEcontaining gasoline. The experiment started in 1988 and was originally designed to observe the transport of MTBE in the subsurface. In 1996 MTBE was observed to be present at only $3 \%$ of the original mass (taking into account dispersion and dilution). The aquifer is underlined by an impermeable clayey layer that sits on top of a confined aquifer with no detectable measurements of MTBE in the confined layer. MTBE was assumed to be removed via biodegradation but the presence of daughter compounds, TBA and TBF, where not detected. Schirmer et al. [19] used microcosms with soils from the Borden aquifer to determine the potential of MTBE and TBA biodegradation. MTBE and TBA were found to degrade with rate constants of $0.04-0.07$ day $^{-1}$ and 0.12 day $^{-1}$, respectively, at $10^{\circ} \mathrm{C}$. The authors postulated that TBA did not accumulate because its biodegradation rate was significantly greater than MTBE.

The removal of TBA at the Ronan site at $25^{\circ} \mathrm{C}$ is significantly less than at the Borden site at $10^{\circ} \mathrm{C}\left(0.0153\right.$ day $^{-1}$ compared to 0.12 day $^{-1}$ ) [19]. However, this is not unexpected since the Ronan site has a measurable presence of TBA (up to $1000 \mu \mathrm{g} / \mathrm{L}$ ) [16].

The study by Day and Gulliver [20] was performed in situ using TBA carbon isotopes $\left({ }^{13} \mathrm{C}\right)$ to follow the fate and transport of TBA in a contaminated shallow aquifer. This is a unique study because TBA was introduced into the aquifer by a surface release of TBA at a chemical plant in Pasadena, Texas and was not introduced via MTBE degradation. The aquifer was determined to be under sulfate

Table I: Mineralization results. $k_{m}, r_{v}$, total percent mineralization, $M_{s o}$, the minimum of the sum of the least squares values for microcosms at $5^{\circ} \mathrm{C}, 15^{\circ} \mathrm{C}$, and $25^{\circ} \mathrm{C}$

\begin{tabular}{cccc}
\hline & & Temperature $\left({ }^{\circ} \mathrm{C}\right)$ & \\
\cline { 2 - 3 } & 5 & 15 & 25 \\
& $7.84 \pm 0.14 \times 10^{-3}$ & $9.07 \pm 0.09 \times 10^{-3}$ & $15.3 \pm 0.3 \times 10^{-3}$ \\
$k_{m}\left(\right.$ days $\left.^{-1}\right)$ & $2.86 \pm 0.05$ & $3.31 \pm 0.03$ & $5.60 \pm 0.14$ \\
$k_{m}\left(\right.$ years $\left.^{-1}\right)$ & $4.89 \times 10^{-3}$ & $5.36 \times 10^{-3}$ & $5.88 \times 10^{-3}$ \\
$r_{p}\left(\right.$ days $\left.^{-1}\right)$ & $54.1 \%$ & $64.4 \%$ & $69.8 \%$ \\
Total mineralization & 1.70 & 1.66 & 1.73 \\
M $_{\text {so }}(\mathrm{mg} / \mathrm{L})$ & 0.16 & 1.50 & 0.50 \\
Sum $\Delta^{2}$ & &
\end{tabular}

$M_{s O}$ : initial mass of TBA in the slurry after the lag phase, $k_{m}$ : first order biodegradation kinetic rate constant, $r_{p}$ : average rate of partitioning of TBA from the slurry 


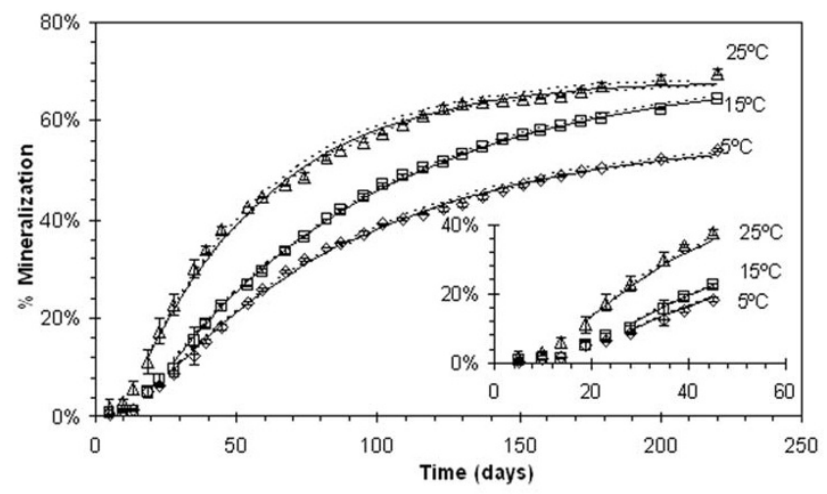

Figure 3

Cumulative measured TBA mineralization showing lag phase and model fit. Non-poison microcosms at $(\diamond) 5^{\circ} \mathrm{C},(\square) 15^{\circ} \mathrm{C}$, and $(\triangle) 25^{\circ} \mathrm{C}$. Error bars represent standard deviation. Solid and dashed lines represent the predicted mass mineralized $\left(\mathrm{M}_{\mathrm{m}}\right)$ and $95 \%$ upper and lower confidence limits. Model does not include the lag phase (days $0-23$ for the $5^{\circ} \mathrm{C}$ and $15^{\circ} \mathrm{C}$ microcosms and days $0-14$ for the $25^{\circ} \mathrm{C}$ microcosms).

reducing conditions and researchers observed TBA first order degradation rate constants of $0.26,0.97$, and 1.1 year ${ }^{-1}$ with temperature range of $7-16^{\circ} \mathrm{C}$. The rate constants observed by Day and Guliver [20] are significantly slower than constants observed in this study (ranging from 2.86 to 5.60 years $^{-1}$ ), which were determined under oxic conditions. This is not unexpected since TBA and MTBE degradation has been observed to be slower under sulfate reducing conditions [17-19,21].

\section{Temperature effects}

The effect of temperature on TBA biodegradation in this study was statistically significant. Application of the data to the linear Arrhenius equation (equation 10) yields constant values of constants A and Ea of 154 day $^{-1}$ and 23,006
mol/J, respectively. Although no other published study has reported a TBA degradation kinetic experiment at different temperatures, a study was performed with MTBE on a Ronan sediment at four temperatures $\left(4^{\circ} \mathrm{C}, 14^{\circ} \mathrm{C}\right.$, $24^{\circ} \mathrm{C}$, and $34^{\circ} \mathrm{C}$ ) by Bradley and Landmeyer [5]. The authors observed that MTBE was mineralized at the fastest rate at $24^{\circ} \mathrm{C}$ and decreased with temperature down to $4{ }^{\circ} \mathrm{C}$ (incubated for 77 days).

Calculation of first order rate constants for MTBE from the data presented in Bradley and Landmeyer [5] yield $4.95 \times$ $10^{-3}, 8.30 \times 10^{-3}, 15.4 \times 10^{-3}$ and $7.09 \times 10^{-3}$ day- 1 values for $4{ }^{\circ} \mathrm{C}, 14^{\circ} \mathrm{C}, 24^{\circ} \mathrm{C}$, and $34^{\circ} \mathrm{C}$ microcosms, respectively. These rates applied to the Arrhenius equation are comparable to the rates determined for TBA in this study (Figure 4) and yield values for A and Ea of 99,509 day $^{-1}$ and $38,800 \mathrm{~mol} \mathrm{~J}^{-1}$. The kinetic rate constant determined for MTBE degradation at $34^{\circ} \mathrm{C}$ was not included in the regression since the Arrhenius equation only models continuous increase in kinetic rates with increases in temperature; also, the annual groundwater temperature at the Ronan site ranges from $14^{\circ} \mathrm{C}$ to $5^{\circ} \mathrm{C}$ and does not exceed $24^{\circ} \mathrm{C}$.

Placing the A and Ea values into equation 9 for MTBE and TBA, setting the equations equal to each other, and solving for $\mathrm{T}$ provides the temperature where MTBE and TBA degradation rates are equal, which is $20.4^{\circ} \mathrm{C}$. Therefore, temperatures below $20.4^{\circ} \mathrm{C}$ will induce kinetic rate constants that are faster for TBA than MTBE. Since the temperature at the Ronan site is below $20.4^{\circ} \mathrm{C}$, it could be assumed that aerobic TBA biodegradation is faster than MTBE. This theory agrees with findings in other published studies that observed similar rates $[17,22,23]$.

The presence of TBA at the Ronan site could be explained by redox conditions in the subsurface in the hyporheic zone. Multiple studies have found that TBA accumulates under anaerobic conditions and most subsurface environments, especially in hyporheic soils and sediments, do not

Table 2: TBA degradation study comparison

\begin{tabular}{|c|c|c|c|c|}
\hline $\begin{array}{l}\text { Terminal Electron } \\
\text { Acceptor }\end{array}$ & TBA Degradation & Degradation Rate & Temp. $\left({ }^{\circ} \mathrm{C}\right)$ & Reference \\
\hline \multirow[t]{6}{*}{ Oxygen } & $54.0 \%$ over 220 days & $7.84 \times 10^{-3} d^{-1}$ & 5 & This Study \\
\hline & $64.4 \%$ over 220 days & $9.07 \times 10^{-3} \mathrm{~d}^{-1}$ & 15 & This Study \\
\hline & $69.8 \%$ over 220 days & $15.3 \times 10^{-3} \mathrm{~d}^{-1}$ & 25 & This Study \\
\hline & $99 \%$ over 198 days & ni & $\mathrm{nr}$ & [I7] \\
\hline & $70 \%$ over 105 days & ni & $\mathrm{nr}$ & [18] \\
\hline & TBA accumulation & $0.12 d^{-1}$ & 10 & {$[19]$} \\
\hline Nitrate & $49 \%$ over 198 days & ni & $\mathrm{nr}$ & {$[17]$} \\
\hline \multirow[t]{2}{*}{ Sulfate } & $5 \%$ over 198 days & $\mathrm{ni}$ & $\mathrm{nr}$ & [17] \\
\hline & in situ & $0.26-1.1$ year-1 & $16-7$ & [20] \\
\hline $\mathrm{Fe}(\mathrm{III})$ & $25 \%$ over 65 days & $\mathrm{ni}$ & $\mathrm{nr}$ & {$[21]$} \\
\hline $\mathrm{Mn}(\mathrm{IV})$ & $75 \%$ over 198 days & $\mathrm{ni}$ & $\mathrm{nr}$ & {$[17]$} \\
\hline
\end{tabular}




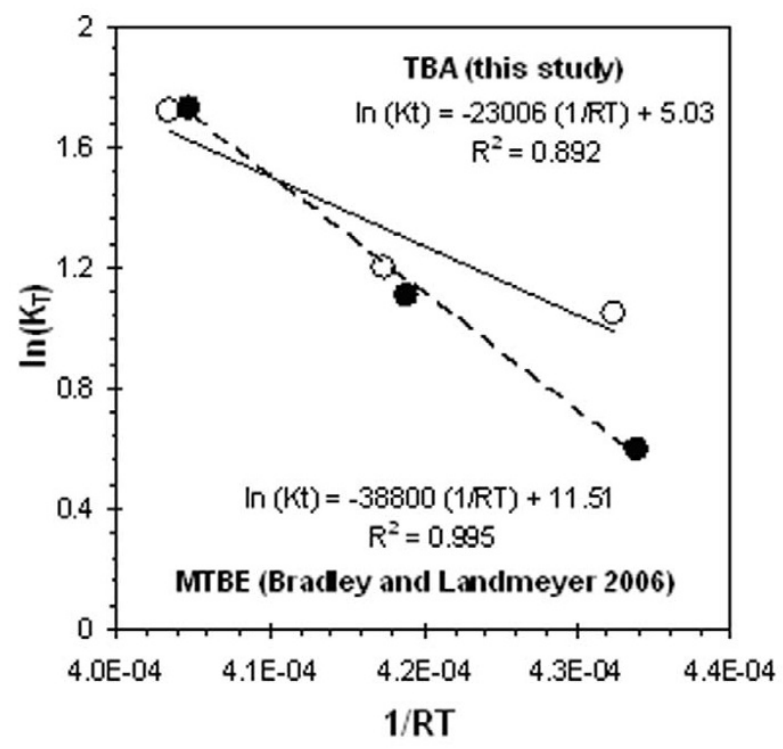

Figure 4

Temperature effects on MTBE and TBA biodegradation rates. Rates from this study for TBA $(\bigcirc)$ and Bradley and Landmeyer [5] for MTBE (๑) applied to the Arrhenius equation.

have homogeneous redox conditions, but include both anoxic and oxic regions $[17,21,24]$.

\section{Discussion and conclusion}

Results from this study have confirmed that TBA degradation is occurring at the Ronan, MT site and that the rate of removal of TBA is affected by temperature. These results provide support of the application of MNA at the site, since it has been demonstrated in laboratory experiments that indigenous microorganisms at the site are capable of degrading both MTBE and TBA.

Biodegradation of TBA should be evaluated further by investigating the effects of dissolved oxygen (DO) concentrations on TBA mineralization rate. Degradation studies with polycyclic aromatic hydrocarbons (PAHs) and pentachlorophenol (PCP) showed that ambient oxygen concentrations in the soil gas phase could be reduced to $2 \%$ $\mathrm{v} / \mathrm{v}$ (or approximately $0.8 \mathrm{mg} / \mathrm{L}$ in the soil aqueous phase) with no significant reduction in mineralization kinetics $[25,26]$. Reporting the effect of DO concentrations in the gaseous phase of the Ronan, MT hyporheic zone soils on the rate and extent of TBA mineralization is planned.

This study also has implications in developing microbiology tools to help determine the use of MNA as remediation. Determination of microbial strains responsible for TBA and MTBE biodegradation at the Ronan site could be used to create a genetic primer to identify other viable microbes at MTBE and TBA contaminated sites. The use of this primer would assist in understanding the ability of the site to degrade the constituents.

\section{Abbreviations}

A: frequency factor; $\mathrm{BaCl}$ : barium chloride; bgs: below ground surface; $\mathrm{C}$ : concentration of TBA; $\mathrm{CO}_{2}$ : carbon dioxide; DOC: dissolved organic carbon; DO: dissolved oxygen; $\mathrm{E}_{\mathrm{a}}$ : activation energy; ETBE: ethyl tert-butyl ether; $\mathrm{HgCl}_{2}$ : mercuric chloride; $\mathbf{k}_{\mathrm{m}}$ : first order mineralization rate; $\mathbf{K O H}$ : potassium hydroxide; LUFT: leaking underground fuel tank; $\mathrm{M}_{\mathrm{m}}$ : measured mass of TBA mineralized; $\mathrm{M}_{\mathrm{mm}}$ : modeled mass of TBA mineralized; MNA: monitored natural attenuation; $\mathrm{M}_{\mathrm{p}}$ : mass of TBA partitioned; $M_{\mathrm{pm}}$ : modeled mass of TBA partitioned; $\mathbf{M}_{\mathrm{s}}$ : mass of TBA in slurry; $\mathrm{M}_{\mathrm{SO}}$ : initial mass of TBA in slurry; MTBE: methyl tert-butyl ether; PAH: polycyclic aromatic hydrocarbon; PCP: pentachlorophenol; $\mathbf{R}$ : ideal gas constant; $\mathbf{r}_{\mathrm{p}}$ : first order partitioning rate; $\mathbf{T}$ : temperature; $\mathbf{t}$ : time; TBA: tertbutyl alcohol; TBF: ter-butyl formate; VOA: volatile organic air-tight; $\mathbf{V}_{\mathrm{S}}$ : volume of slurry

\section{Competing interests}

The author(s) declare that they have no competing interests.

\section{Authors' contributions}

MHG carried out field sampling, mineralization studies, derived the mineralization model and drafted the manuscript. RCS conceived the study and participated in its design. JEM participated in data interpretation and statistical analysis and WJD assisted in microcosm design and empirical modeling of the data. All authors read and approved the final manuscript.

\section{Acknowledgements}

We thank the American Petroleum Institute for funding this and past projects at the Ronan site and also Jeff Kuhn of the Montana Department of Environmental Quality for his assistance in accessing the site and collecting samples. The Huntsman Environmental Research Center also provided support for sampling, analysis, and student stipends.

\section{References}

I. Kern EA, Veeh RH, Langner HW, Macur RE, Cunningham AB: Characterization of methyl tert-butyl ether degrading bacteria from a gasoline-contaminated aquifer. Biorem J 2002, 6(2): I I3-124.

2. Ramsden DK, Li T: USEPA case studies database for MTBE remediation. In MTBE Remediation Handbook Edited by: Moyer EE, Kostecki PT. Amherst, Amherst Scientific Publishers; 2003:337-394.

3. Wiedemeier TH, Swanson MA, Moutoux DE, Wilson JT, Kampbell $\mathrm{DH}$, Hansen JE, Haas P: Overview of the technical protocol for natural attenuation of chlorinated aliphatic hydrocarbons in ground water under development for the U.S. Air Force Center for Environmental Excellence. In Symposium on Natural Attenuation of Chlorinated Organics in Ground Water EPA-540-R-96-509, U.S EPA, Washington, D.C.; 1996:35-59.

4. Chapelle FH: Groundwater Microbiology and Geochemistry New York: John Wiley and Sons; 2001. 
5. Bradley PM, Landmeyer JE: Low-temperature MTBE biodegradation in aquifer sediments with history of low, seasonal ground water temperature. Ground Water Monit Rem 2006, 26(I): $101-105$.

6. Eriksson M, Ka J-O, Mohn WW: Effects of low temperature and freeze-thaw cycles on hydrocarbon biodegradation in arctic tundra soil. Appl Environ Microbiol 200 I, 67(I I):5I07-5II2.

7. Eriksson M, Sodersten E, Yu Z, Dalhammar G, Mohn WW: Degradation of polycyclic aromatic hydrocarbons at low temperature under aeroboc and nitrate-reducing conditions in enrichment cultures from northern soils. Appl Environ Microbiol 2003, 69(I):275-284.

8. Whyte LG, Hawari J, Zhou E, Bourbonniere L, Inniss WE, Greer CW: Biodegradation of variable chain-length alkanes at low temperatures by a psychrotrophic Rhodococcus sp. Appl Environ Microbiol 1998, 64(7):2578-2584.

9. Rosell M, Lacorte S, Barcelo D: Analysis, occurrence and fate of MTBE in the aquatic environment over the past decade. Trends Anal Chem 2006, 25(10): 1016-1029.

10. Schmidt TC, Morgenroth E, Schirmer M, Effenberger M, Haderlein SB: Use and occurrence of fuel oxygenates in Europe. In Oxygenates in gasoline: environmental aspects Edited by: Diaz AF, Drogos DL. Washington, American Chemical Society; 2003:58-79.

II. Cirvello JD, Radovsky A, Heathm JE, Farnell DR, Lindamood C: Toxicity and carcinogenicity of $t$-butyl alcohol in rats and mice following chronic exposure in drinking water. Toxicol Ind Health 1995, II:15I-165.

12. Greenwood MH, Sims RC, McLean JE, Doucette WJ: Sorption of methyl tert-butyl ether (MTBE) and tert-butyl alcohol (TBA) to hyporheic zone soils. Soil Sediment Contam 2007, 16(4):423-43I.

13. Boulton AJ, Findlay S, Marmonier P, Stanley EH, Valett HM: The functional significance of the hyporheic zone in streams and rivers. Annu Rev Ecol Syst 1998, 29:59-8I.

14. Findlay S, Stayer D, Goumbala C, Gould K: Metabolism of streamwater dissolved orgainc carbon in the shallow hyporheic zone. Limnol Oceanog 1993, 38(7): 1493-1499.

15. Findlay S: Importance of surface-subsurface exchange in stream ecosystems: the hyporheic zone. Limnol Oceanog 1995, 40(I): 159-164.

16. Loustaunau KP: Transport and fate of methyl tertiary butyl ether (MTBE) in a floodplain aquifer and a stream interface, Ronan Montana. In Masters Thesis Department of Geology, University of Montana; 2003.

17. Bradley PM, Landmeyer JE, Chapelle FH: TBA biodegradation in surface water sediments under aerobic and anaerobic conditions. Environ Sci Technol 2002, 36(19):4087-4090.

18. Bradley PM, Landmeyer JE, Chapelle FH: Aerobic mineralization of MTBE and tert-butyl alcohol by stream-bed sediment microorganisms. Environ Sci Technol 1999, 33(I): 1877-I879.

19. Schirmer M, Butler BJ, Church CD, Barker JF, Nadajarah N: Laboratory evidence of MTBE biodegradation in borden aquifer material. J Contam Hydrol 2003, 60:229-249.

20. Day MJ, Gulliver T: Rate of natural attenuation of tert-butyl alcohol at a chemical plant. Soil Sedim Contam 2003, I 2: I | 9 - 138

21. Finneran KT, Lovely DR: Anaerobic degradation of methyl tertbutyl ether (MTBE) and tert-butyl alcohol (TBA). Environ Sci Technol 200I, 35(9): 1785-1790.

22. Bradley PM, Landmeyer JE, Chapelle FH: Widespread potential for microbial MTBE degradation in surface-water sediments. Environ Sci Technol 200I, 35(4):658-662.

23. Wilson RD, Mackay DM, Scow KM: In situ biodegradation supported by diffuse oxygen release. Environ Sci Technol 2002, 36(2): 190-199.

24. Yeh CK, Novak JT: Anaerobic biodegradation of gasoline oxygenates in soils. Water Environ Res 1994, 66(5):744-752.

25. Hurst CJ, Sims RC, Sims JL, Sorensen DL, McLean JE, Huling S: Polycyclic aromatic hydrocarbon biodegradation as a function of oxygen tension in contaminated soil. Hazard Mate 1996, 51:193-208.

26. Hurst CJ, Sims RC, Sims JL, Sorensen DL, McLean JE, Huling S: Soil gas oxygen tension and pentachlorophenol biodegradation. Environ Engineer 1997:364-370.
Publish with Biomed Central and every scientist can read your work free of charge

"BioMed Central will be the most significant development for disseminating the results of biomedical research in our lifetime. "

Sir Paul Nurse, Cancer Research UK

Your research papers will be:

- available free of charge to the entire biomedical community

- peer reviewed and published immediately upon acceptance

- cited in PubMed and archived on PubMed Central

- yours - you keep the copyright
BioMedcentral 